\title{
Representasi Mutasi Kode Genetik Standar Berdasarkan Basa Nukleotida
}

\author{
Isah Aisah, Edi Kurniadi, Ema Carnia, Nurul Ula \\ Program Studi S1 Matematika FMIPA Universitas Padjadjaran \\ Jalan Raya Bandung Sumedang KM 21 Jatinangor Sumedang 45363 \\ Email: isah_aish@yahoo.co.id
}

\begin{abstract}
ABSTRAK
Kode genetik standar merupakan hasil pemikiran para ilmuwan biologi pada masanya sebagai suatu representasi gen yang disesuaikan dengan kebutuhan tubuh manusia akan protein. Gen pada kode genetik standar disajikan dalam bentuk kode triplet basa-basa nitrogen dan menjadi bahasa pengkodean gen dalam tubuh makhluk hidup yang menghasilkan $4^{3}=64$ kode triplet yang berbeda. Semua kode triplet dari rantai nukleotida RNA tersebut diterjemahkan dan menghasilkan 20 macam asam amino yang akan dilepas sebagai protein dalam sel. Kumpulan basa nitrogen dalam rantai RNA dihimpun dan disajikan dalam suatu himpunan $N=\{C, U, A, G\}$ yang kemudian dicocokkan dengan $\mathbb{Z}_{2} \times \mathbb{Z}_{2}=\{(1,1),(1,0),(0,0),(0,1)\}$ dengan dua himpunan yang memuat partisi basabasa nitrogen berdasarkan jenis basa dan ikatan hidrogennya Pada paper ini himpunan $N=\{C, U, A, G\}$ dicocokkan $\mathbb{Z}_{2} \times \mathbb{Z}_{2}=\{(0,0),(1,0),(0,1),(1,1)\}$. Dengan pencocokan tersebut, maka $N$ memiliki struktur Aljabar sebagai Grup Komutatif terhadap penjumlahan, juga membentuk Grup Faktor yang dibentuk dari subgroup Normal yaitu $\{(\overline{0}, \overline{0}),(\overline{1}, \overline{1})\}=\langle(\overline{1}, \overline{1})\rangle$, dan Lapangan Galois atau GF(4). Selain dari itu, NNN juga membentuk struktur ruang vektor atas $\mathrm{GF}(4)$ sehingga $N N N \subseteq \mathbb{R}^{3}$. Dengan demikian terbentuklah representasi NNN berupa suatu multicube NNN berdimensi tiga yang merupakan gabungan dari 27 kubus unitary, dengan menggunakan transformasi geometri, maka akan dilihat representasi dari kode genetik Standar berdasarkan subgrup normal yang membentuk grup faktornya, yaitu didasarkan pada basa kuat atau basa lemah dari Nukleotida. Representasi dilakukan dengan menggunakan bantuan software Geogebra. Dari hasil representasi tersebut dapat dilihat perubahan-perubahan yang terjadi pada kode genetik standar, yang pada akhirnya dapat dipandang sebagai mutasi pada kajian ilmu Biologi Sel.
\end{abstract}

Kata kunci: RNA, Kode Genetik Standar, Representasi

\section{ABSTRACT}

Standard genetic code is the brainchild of biological scientists of his time as a representation of genes that are tailored to the needs of the human body protein. Genes in the genetic code of standards presented in the form of the triplet code nitrogen bases and into the language encoding genes in the living body which produce $\mathbf{4}^{\mathbf{3}}=\mathbf{6 4}$ different triplet code. All code is a triplet of nucleotides RNA chain is translated right and produce 20 kinds of amino acids to be released as a protein in the cell. The set of nitrogenous bases in the RNA chain compiled and presented in a set $N=\{C$, $U, A, G\}$ are then matched with $\mathbb{Z}_{\mathbf{2}} \times \mathbb{Z}_{\mathbf{2}}=\{(\mathbf{1}, \mathbf{1}),(\mathbf{1}, \mathbf{0}),(\mathbf{0}, \mathbf{0}),(\mathbf{0}, \mathbf{1})\}$ with two sets that contain nitrogen bases partition based on the type of base and bonding hidrogen, this paper the set $N=\{C, U, A, G\}$ matched $\mathbb{Z}_{2} \times \mathbb{Z}_{2}=$ $\{(\mathbf{0}, \mathbf{0}),(\mathbf{1}, \mathbf{0}),(\mathbf{0}, \mathbf{1}),(\mathbf{1}, \mathbf{1})\}$. With the matching, then $N$ has structures Commutative Algebra as a group under addition, also form factor groups formed from Normal subgroups, namely $\{(\overline{\mathbf{0}}, \overline{\mathbf{0}}),(\overline{\mathbf{1}}, \overline{\mathbf{1}})\}=\langle(\overline{\mathbf{1}}, \overline{\mathbf{1}})\rangle$, and Galois Field or GF (4). Aside from that, NNN also form a vector space structure over $G F(4)$. So $N N N \subseteq \mathbb{R}^{3}$. Thus forming a representation of NNN form a three-dimensional multicube which is a combination of 27 unitary cube, using geometric transformations, it will be a representation of the genetic code based on the standard normal subgroups that make up the group factor, which is based on a strong base or a weak base of the nucleotide. Representation is done with the help of software GeoGebra. From the results of these representations can be seen the changes that occur in the standard genetic code.

Keywords: RNA, Standard Genetic Code, Representation

\section{Pendahuluan}

Kajian genetika klasik dimulai dari gejala fenotip yang tampak oleh pengamatan manusia kemudian dicarikan penjelasan genotipiknya hingga ke arah gen. Berkembangnya teknik-teknik dalam genetika molekular secara cepat dan efisien memunculkan filosofi baru dalam metodologi genetika, dengan membalik arah kajian. Karena banyak gen yang sudah diidentifikasi sekuensnya, orang memasukkan atau mengubah suatu gen dalam kromosom lalu melihat implikasi fenotipik yang terjadi. 
DNA berfungsi mengontrol sintesis protein melalui RNA (ribonucleic acid). Suatu molekul RNA terdiri atas satu untai tunggal dan secara kimiawi serupa dengan DNA, hanya saja pada RNA ribosa- lah sebagai gulanya dan basa nitrogen timin (T) diganti dengan urasil (U). Basa RNA disusun pada cetakan DNA maka dalam pengkodean digunakan urasil (U) untuk menentukan kodon dari himpunan basa nukleotida $\{\mathrm{A}, \mathrm{C}, \mathrm{G}, \mathrm{U}\}$ yang diurutkan berdasarkan perbedaan sifat kimiawi nukleotida (purin dan pirimidin) dan ikatan hidrogen basa komplementer (Robersy Sanchez et al., 2007).

Kumpulan basa nitrogen dalam rantai RNA dapat juga disajikan dalam suatu himpunan $\mathrm{N}=$ $\{C, U, A, G\}$. Pada artikel (Montano et al, $1996: 119$ ), $N$ kemudian dicocokkan dengan $\mathbb{Z}_{2} \times \mathbb{Z}_{2}=$ $\{(1,1),(1,0),(0,0),(0,1)\}$ dengan dua himpunan yang memuat partisi basa-basa nitrogen berdasarkan jenis basa dan ikatan hidrogennya. Selanjutnya dalam artikel (Jose et al, $2006: 217$ ) himpunan $\mathrm{N}=\{\mathrm{C}, \mathrm{U}, \mathrm{A}, \mathrm{G}\}$ dicocokkan dengan $\mathbb{Z}_{2} \times \mathbb{Z}_{2}=\{(0,0),(1,0),(0,1),(1,1)\}$.

Melalui pencocokan tersebut maka $\mathrm{N}$ dapat dikaji struktur Aljabarnya serta dapat dilihat representasi dari mutasinya.

\section{Metode Penelitian}

Objek Penelitian ini adalah Kode Genetik Standar yang akan diteliti struktur Aljabarnya, kemudian direpresentasi kedalam bentuk Hypercube melalui pencocokan $\mathrm{N}$ dengan $\mathrm{Z}_{2} \mathrm{X} \mathrm{Z}_{2}$. Representasi yang dilakukan hanya dibatasi berdasarkan salah satu partisi yang ada pada Kode genetic standar yaitu basa nukleotida.

Adapun alur penelitian yang dilakukan dapat dilihat pada gambar berikut :

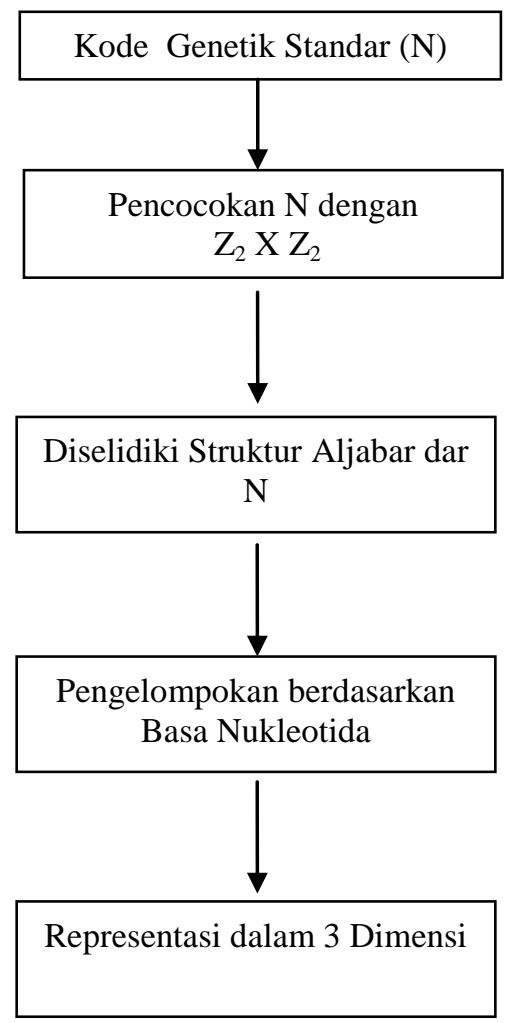

Gambar 1. Diagram Alur Tahapan Representasi Kode Genetik Standar

\section{Hasil dan Pembahasan}

Untuk melihat struktur Aljabar dari Kode Genetik standar akan diberikan beberapa definisi yang berhubungan dengan struktur Aljabar.

Definisi 1 (Herstein, 1964). Suatu himpunan tak kosong $G$ dikatakan membentuk sebuah grup jika pada $G$ didefinisikan suatu operasi biner dinotasikan oleh ${ }^{\text { }}$, sedemikian sehingga122 
1) Untuk setiap $a, b, c \in G$ berlaku $a \cdot(b \cdot c)=(a \cdot b) \cdot c$ (hukum asosiatif)

2) Terdapat suatu unsur $e \in G$ sedemikian sehingga $a \cdot e=e \cdot a=a$ untuk setiap $a \in G$ (eksistensi suatu unsur identitas di $G$ )

3) Untuk setiap $a \in G$ terdapat suatu unsur $a^{-1} \in G$ sedemikian sehingga $a \cdot a^{-1}=a^{-1} \cdot a=e$ (eksistensi invers di $G$ )

Definisi 2 (Derek, 2003). Grup Klein-4 adalah grup dengan order empat dimana setiap elemen adalah invers bagi dirinya sendiri.

Misalkan keempat basa nitrogen pada himpunan $\mathrm{N}=\{\mathrm{C}, \mathrm{U}, \mathrm{A}, \mathrm{G}\}$ dilakukan pencocokan $\mathrm{C}=(\overline{0}, \overline{0}), \mathrm{U}=$ $(\overline{0}, \overline{1}), A=(\overline{1}, \overline{0})$, dan $G=(\overline{1}, \overline{1})$, maka akan dilihat struktur dari $\mathbf{N}$. Dengan menggunakan table Cayley berikut :

Tabel 1. Tabel cayley $\mathrm{N}$ terhadap penjumlahan

\begin{tabular}{|c|c|c|c|c|}
\hline+ & C & U & A & G \\
\hline C & C & U & A & G \\
\hline U & U & C & G & A \\
\hline A & A & G & C & U \\
\hline G & G & A & U & C \\
\hline
\end{tabular}

Maka N mempunyai struktur grup Abelian terhadap +, Karena setiap unsur mempunyai invers dirinya sendiri maka $\mathrm{N}$ membentuk grup Klein-4 terhadap penjumlahan.

Berdasarkan sifat kimia nukleotida, para ilmuwan Biologi mengklasifikasikan $\mathrm{N}$ kedalam tiga himpunan partisi yaitu himpunan $\wp_{1}=\{\{C, G\},\{U, A\}\}, \wp_{2}=\{\{C, A\},\{U, G\}\}$, dan $\wp_{1}=\{\{C, U\},\{A, G\}\}$. Untuk himpunan pertama, $\wp_{1}$ berdasarkan klasifikasi biologi basa kuat nukleotida yang membentuk tiga ikatan hydrogen $S=\{C, G\}$ dan basa lemah nukleotida yang membentuk dua ikatan hidrogen $W=\{U, A\}$. Untuk himpunan kedua, $\wp_{2}$ didasarkan pada klasifikasi kimia nukleotida yaitu amino nukleotida $M=\{C, A\}$ dan keto nukleotida $K=\{U, G\}$. Himpunan ketiga $\wp_{2}$ didasarkan pada jenis basa nukleotida yaitu pirimidin $Y=\{C, U\}$ dan purin $R=\{A, G\}$.

Dipandang dari struktur Aljabar yang dipelajari, maka himpunan partisi-partisi tersebut dapat dilihat sebagai Grup Faktor yang dibentuk dari Grup Klein4, yang dapat dilihat sebagai berikut:

$(N,+)$ adalah grup Klein-4 yang mempunyai subgrup-subgrup normal yaitu

$H_{1}=\{(\overline{0}, \overline{0}),(\overline{0}, \overline{1})\}=\langle(\overline{0}, \overline{1})\rangle, H_{2}=\{(\overline{0}, \overline{0}),(\overline{1}, \overline{0})\}=\langle(\overline{1}, \overline{0})\rangle$, dan $H_{1}=\{(\overline{0}, \overline{0}),(\overline{1}, \overline{1})\}=\langle(\overline{1}, \overline{1})\rangle$. Sehingga terbentuk tiga grup faktor, yaitu

$\mathrm{N} / \mathrm{H}_{1}=\{((\overline{0}, \overline{1})\rangle+(\overline{0}, \overline{0}),\langle(\overline{0}, \overline{1})\}+(\overline{1}, \overline{0})\}=\left\{\left\{C_{v},\right\}_{s}\{\mathrm{~A}, \mathrm{G}\}\right\}=\wp_{a}$

$\mathrm{N} / \mathrm{H}_{2}=\left\{\left(\left(\overline{1}_{v}, \overline{0}\right)\right\rangle+(\overline{0}, \overline{0}),\left\langle\left(\overline{1}_{v}, \overline{0}\right)\right\rangle+(\overline{0}, \overline{1})\right\}=\left\{\left\{\mathrm{C}_{x} \mathrm{~A}\right\},\left\{\mathrm{U}_{v} \mathrm{G}\right\}\right\}=\wp_{2}$,

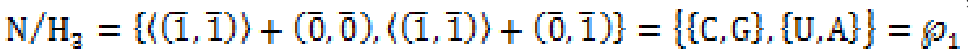

Karena NNN juga membentuk struktur ruang vektor atas $\mathrm{GF}(4)$, sehingga $N N N \subseteq \mathbb{R}^{3}$ dengan demikian NNN mempunyai basis standar yaitu $\left\{e_{1}, e_{2}, e_{3}, e_{4}, e_{5}, e_{6}\right\} \quad \operatorname{dimana} e_{1}=\{\overline{1}, \overline{0}, \overline{0}, \overline{0}, \overline{0}, \overline{0}\}$, $e_{2}=\{\overline{0}, \overline{1}, \overline{0}, \overline{0}, \overline{0}, \overline{0}\}, \quad e_{3}=\{\overline{0}, \overline{0}, \overline{1}, \overline{0}, \overline{0}, \overline{0}\}, \quad e_{4}=\{\overline{0}, \overline{0}, \overline{0}, \overline{1}, \overline{0}, \overline{0}\}, \quad e_{5}=\{\overline{0}, \overline{0}, \overline{0}, \overline{0}, \overline{1}, \overline{0}\}, \quad$ dan $\quad e_{6}=$ $\{\overline{0}, \overline{0}, \overline{0}, \overline{0}, \overline{0}, \overline{1}\}$. Keenam basis tersebut merupakan basis ortonormal karena mempunyai panjang atau norm 1 dan setiap dua vektor basisnya saling ortogonal, yaitu hasil kali titik antara setiap dua vektor adalah 0. Sehingga terbentuklah representasi NNN berupa suatu multicube NNN berdimensi tiga yang merupakan gabungan dari 27 kubus unitary dimana berdasarkan definisi Jarak Hamming, panjang atau jarak setiap dua kodon yang terhubung adalah 1. 


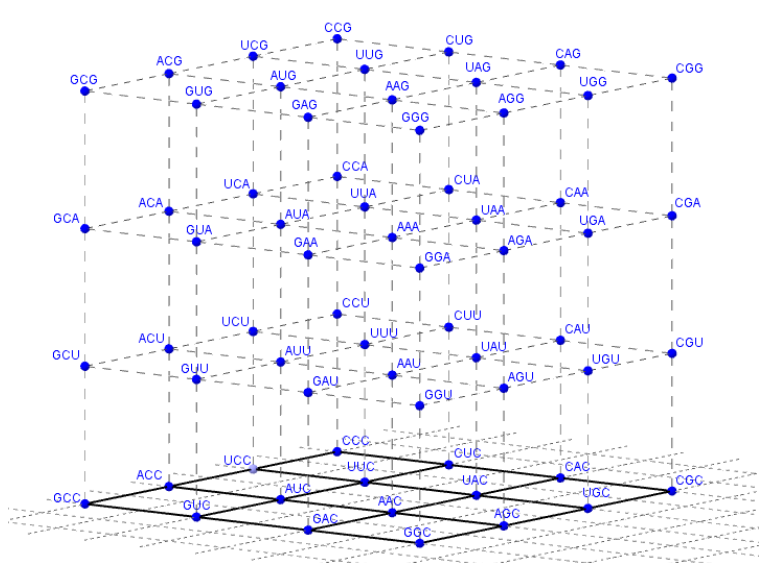

Gambar 2. Representasi Kode Genetik Standar dalam Multicube NNN

Dalam Ilmu Genetika, dikenal istilah mutasi, yaitu perubahan genetik (gen atau kromosom) dari suatu individu yang bersifat menurun (Pratiwi,dkk.2012). Ketika pirimidin diganti oleh pirimidin yang lain, atau purin oleh purin yang lain, mutasi disebut transisi. Ketika pirimidin diganti oleh purin, atau sebaliknya, mutasi disebut transversi. Terdapat dua jenis transversi yang berbeda, berdasarkan $\wp_{2}$ (klasifikasi amino-keto) dan kedua yang mengganti suatu nukleotida ke nukleotida lainnya pada kelas yang sama berdasarkan $\wp_{1}$ (klasifikasi kuat-lemah basa). Transformasi yang terakhir adalah transfomasi yang mengubah nukleotida-nukleotida dengan komplemennya.

\subsection{Peran Translasi sebagai Representasi dari Mutasi}

$(\mathrm{N},+)$ adalah grup Abelian. Himpunan $\mathrm{T}(\mathrm{N})=\left\{\mathrm{T}_{00}, \mathrm{~T}_{01}, \mathrm{~T}_{10}, \mathrm{~T}_{11}\right\}$ merupakan himpunan semua transformasi di $\mathrm{N}$ yang kemudian lebih khusus jenis transformasinya adalah translasi. $T_{00}$ adalah translasi dengan vektor $(\overline{0}, \overline{0}), T_{01}$ adalah translasi dengan vektor $(\overline{0}, \overline{1}), T_{10}$ adalah translasi dengan vektor $(\overline{1}, \overline{0})$ dan $T_{11}$ adalah translasi dengan vektor $(\overline{1}, \overline{1})$ Perhatikan tabel berikut :

Tabel 2. Tabel Cayley $T(N)$ terhadap komposisi

\begin{tabular}{|c|c|c|c|c|}
\hline$\circ$ & $\mathbf{T}_{\mathbf{0 0}}$ & $\mathbf{T}_{\mathbf{0 1}}$ & $\mathbf{T}_{\mathbf{1 0}}$ & $\mathbf{T}_{\mathbf{1 1}}$ \\
\hline $\mathbf{T}_{\mathbf{0 0}}$ & $\mathrm{T}_{00}$ & $\mathrm{~T}_{01}$ & $\mathrm{~T}_{10}$ & $\mathrm{~T}_{11}$ \\
\hline $\mathbf{T}_{\mathbf{0 1}}$ & $\mathrm{T}_{01}$ & $\mathrm{~T}_{00}$ & $\mathrm{~T}_{11}$ & $\mathrm{~T}_{10}$ \\
\hline $\mathbf{T}_{10}$ & $\mathrm{~T}_{10}$ & $\mathrm{~T}_{11}$ & $\mathrm{~T}_{00}$ & $\mathrm{~T}_{01}$ \\
\hline $\mathbf{T}_{11}$ & $\mathrm{~T}_{11}$ & $\mathrm{~T}_{10}$ & $\mathrm{~T}_{01}$ & $\mathrm{~T}_{00}$ \\
\hline
\end{tabular}

Dengan memperhatikan Tabel Cayley, maka Himpunan $\mathrm{T}(\mathrm{N})=\left\{\mathrm{T}_{00}, \mathrm{~T}_{01}, \mathrm{~T}_{10}, \mathrm{~T}_{11}\right\}$ merupakan grup. $(N,+)$ adalah grup Abelian dan $\left(T(N),{ }^{\circ}\right)$ adalah grup. Perhatikan konstruksi pengaitan berikut.

$$
\begin{gathered}
\mu: \mathrm{N} \rightarrow \mathrm{T}(\mathrm{N}) \\
\mathrm{C} \mapsto \mathrm{T}_{00} \\
\mathrm{U} \mapsto \mathrm{T}_{01} \\
\mathrm{~A} \mapsto \mathrm{T}_{10} \\
\mathrm{G} \mapsto \mathrm{T}_{11}
\end{gathered}
$$

Berdasarkan pengaitan diatas, $\mu$ merupakan pemetaan yang bersifat satu-satu dan pada. Selanjutnya, karena $\mu(X+Y)=\mu(X)+\mu(Y)$ untuk setiap $X, Y \in N$ maka $\mu$ homomorfisma. Sehingga $(N,+) \cong$ $\left(T(N),{ }^{\circ}\right)$

Berdasarkan isomorfisma antara $\mathrm{N}$ dengan $\mathrm{T}(\mathrm{N})$, diperoleh empat translasi yang mungkin untuk merepresentasikan mutasi gen adalah $T_{C}, T_{U}, T_{A}$, dan $T_{G}$. Translasi $T_{C}$ adalah translasi yang mempertahankan struktur dari tiga partisi $\wp_{1}, \wp_{2}$ dan $\wp_{3}$ dari N. Tiga translasi non trivial lainnya diilustrasikan dalam diagram berikut. 


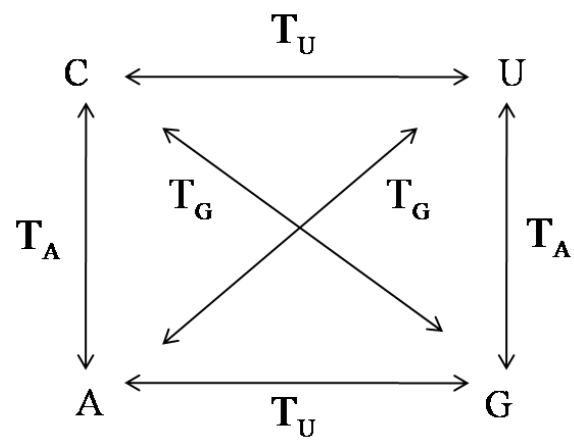

Gambar 3. Translasi Non Trivial

Seperti terlihat dalam diagram, translasi $\mathrm{T}_{\mathrm{U}}$ menunjukkan transisi yang mempertahankan anggota partisi $\wp_{a}$ (klasifikasi pirimidin-purin) namun menukar anggota partisi $\wp_{1}$ dan $\wp_{2}$. Translasi $\mathrm{T}_{\mathrm{A}}$ menunjukkan transversi yang mempertahankan anggota partisi $\wp_{2}$ (klasifikasi amino-keto nukleotida) dan menukar anggota partisi $\wp_{1}$ dan $\wp_{\mathrm{a}}$. Translasi $T_{G}$ menunjukkan transversi pula, tetapi mempertahankan anggota partisi $\wp_{1}$ (klasifikasi kuat-lemah basa) dan mempertahankan anggota partisi $\wp_{2}$ dan $\wp_{\mathrm{a}}$. Dapat disimpulkan bahwa empat translasi mempertahankan himpunan $\left\{\wp_{1}, \wp_{2}, \wp_{a}\right\}$ dari tiga partisi $\wp_{1}, \wp_{2}$ dan $\wp_{a}$.

\subsection{Representasi Mutasi Berdasarkan Himpunan $\wp_{1}$}

Pencocokan awal adalah urutan ( $C, U, A, G)$ yang akan dikaitkan dengan himpunan $\wp_{1}$. Translasi-translasi $\mathrm{T}_{\mathrm{C}}, \mathrm{T}_{\mathrm{U}}, \mathrm{T}_{\mathrm{A}}$ dan $\mathrm{T}_{\mathrm{G}}$ merupakan empat jenis transformasi pertama yang digunakan dalam $\wp_{1}$. Karena dari keempat transformasi tersebut akan dihasilkan bayangan atau hasil transformasi yang termasuk ke dalam anggota $\wp_{1}$. Berdasarkan Gambar 4.2 dengan menggunakan keempat translasi $T_{\mathbb{C}}, T_{\mathbb{U}}, T_{A}$ dan $T_{G}$ pada pengurutan awal $(C, U, A, G)$ akan dihasilkan pengurutan $\left(\mathrm{C}_{v} \mathrm{U}, \mathrm{A}, \mathrm{G}\right),(\mathrm{U}, \mathrm{C}, \mathrm{G}, \mathrm{A}),(\mathrm{A}, \mathrm{G}, \mathrm{C}, \mathrm{U})$ dan $(\mathrm{G}, \mathrm{A}, \mathrm{U}, \mathrm{C})$.

Selanjutnya, dari keenam matriks yang merupakan representasi dari automorfisma yang telah dipaparkan sebelumnya, hanya matriks $I_{2}=\left[\begin{array}{ll}\overline{1} & \overline{0} \\ \overline{0} & \overline{1}\end{array}\right]$ dan $P_{12}=\left[\begin{array}{ll}\overline{0} & \overline{1} \\ \overline{1} & \overline{0}\end{array}\right]$ yang jika dikomposisikan dengan keempat translasi di atas akan menghasilkan bayangan atau hasil transformasi di $\wp_{1}$. Sehingga diperoleh $P_{12}, \mathrm{~T}_{\mathrm{U}} \circ P_{12}, \mathrm{~T}_{\mathrm{A}} \circ P_{12}$ dan $\mathrm{T}_{\mathrm{G}} \circ P_{12}$ menjadi empat jenis transformasi kedua yang termasuk ke dalam $\wp_{1}$.

$P_{12}$ adalah matriks transformasi refleksi terhadap garis $y=x$, sehingga $P_{12}$ akan mengubah $\mathrm{U}$ menjadi A dan sebaliknya serta mempertahankan C dan G. Sehingga jika pengurutan awal $(\mathrm{C}, \mathrm{U}, \mathrm{A}, \mathrm{G})$ dikenakan transformasi dengan menggunakan matriks $P_{12}$, maka hasil pengurutannya adalah $(\mathrm{C}, \mathrm{A}, \mathrm{U}, \mathrm{G})$ dan jenis transformasinya adalah transformasi linear.

Untuk tiga transformasi lainnya yaitu $\mathrm{T}_{\mathrm{U}} \circ P_{12}, \mathrm{~T}_{\mathrm{A}} \circ P_{12}$ dan $\mathrm{T}_{\mathrm{G}} \circ P_{12}$ berdasarkan definisi merupakan transformasi affine. Jika pengurutan awal dikenakan transformasi $\mathrm{T}_{\mathrm{U}} \circ P_{12}$, maka transformasi pertama yang dikenakan adalah transformasi dengan matriks $P_{12}$, sehingga pengurutan awal $\left(C, U_{v}, A, G\right)$ akan menjadi $(C, A, U, G)$ yang kemudian dikenakan lagi translasi $\mathbb{T}_{\mathrm{U}}$. Berdasarkan Gambar $3.2\left(C_{s}, A_{w} \mathrm{U}, \mathrm{G}\right)$ menjadi pengurutan $\left(\mathrm{U}_{s}, \mathrm{G}_{s}, \mathrm{C}_{s} \mathrm{~A}\right)$.

Dengan cara yang sama, hasil transformasi $\mathrm{T}_{\mathrm{A}} \circ P_{12}$ adalah $(\mathrm{A}, \mathrm{C}, \mathrm{G}, \mathrm{U})$ dan $\mathrm{T}_{\mathrm{G}} \circ P_{12}$ adalah $(\mathrm{G}, \mathrm{U}, \mathrm{A}, \mathrm{C})$.

Berikut disajikan representasi perubahan pengurutan dari $(C, U, A, G)$ berdasarkan transformasi $\mathrm{T}_{\mathrm{U}}, \mathbf{T}_{\mathrm{G}}, \mathbf{T}_{\mathrm{G}} \circ \boldsymbol{P}_{12}, \mathbf{T}_{\mathrm{U}} \circ \boldsymbol{P}_{12}$ Ke dalam multicube NNN melalui dua kubus unitary yang dapat dipandang sebagai suatu subset dari multicube NNN. 


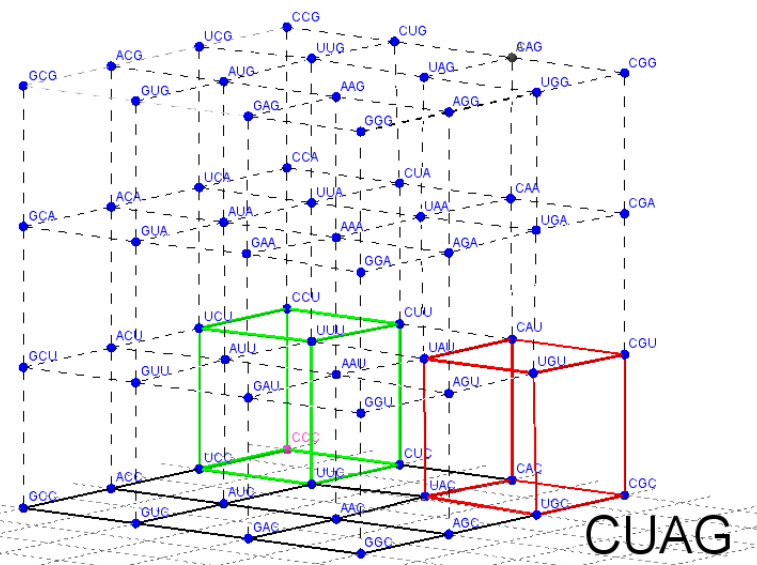

Gambar 4. Model 3 Dimensi Pengurutan Awal (C, U, A, G)

Untuk transformasi berupa translasi $\mathbb{T}_{\mathbb{U}}$, setiap kodon yang menjadi titik sudut multicube pada pengurutan awal $\left(C_{v}, U_{s}, A, G\right)$ diubah pengurutannya menjadi pengurutan $\left(\mathrm{U}, \mathrm{C}_{v}, \mathrm{G}, \mathrm{A}\right)$. Artinya setiap basa $\mathbf{C}$ diubah menjadi basa $\mathbf{U}$ dan sebaliknya serta setiap basa $\mathbf{A}$ diubah menjadi basa $\mathbf{G}$ dan sebaliknya.

Dari pengurutan awal $(C, U, A, G)$ misalkan dipilih kodon atau triplet $\mathrm{CGU}=(\mathrm{C}, \mathrm{G}, \mathrm{U})$. Bayangan atau hasil transformasinya diperoleh melalui perhitungan berikut :

- Untuk basa $\mathrm{C}$ urutan pertama pada urutan $(\mathrm{C}, \mathrm{G}, \mathrm{U})$

$$
\mathrm{T}_{\mathrm{U}}(\mathrm{C})=\mathrm{T}_{[\overline{\mathrm{l}}}\left(\left[\begin{array}{l}
\overline{0} \\
\overline{0}
\end{array}\right]\right)=\left[\begin{array}{l}
\overline{0} \\
\overline{1}
\end{array}\right]+\left[\begin{array}{l}
\overline{0} \\
\overline{0}
\end{array}\right]=\left[\begin{array}{l}
\overline{0} \\
\overline{1}
\end{array}\right]=\mathrm{U}
$$

Jadi, bayangan $\mathrm{C}=\mathrm{U}$.

- Untuk basa $\mathrm{G}$ urutan kedua pada pengurutan $(\mathrm{C}, \mathrm{G}, \mathrm{U})$

$$
\mathrm{T}_{\mathrm{U}}(\mathrm{G})=\mathrm{T}_{[\mathbb{1}]}\left(\left[\begin{array}{l}
\overline{1} \\
\overline{1}
\end{array}\right]\right)=\left[\begin{array}{l}
\overline{0} \\
\frac{1}{1}
\end{array}\right]+\left[\begin{array}{l}
\overline{1} \\
\overline{1}
\end{array}\right]=\left[\begin{array}{l}
\overline{1} \\
\overline{0}
\end{array}\right]=\mathrm{A}
$$

Jadi, bayangan $\mathrm{G}=\mathrm{A}$.

- Untuk basa $U$ urutan ketiga pada pengurutan $\left(C_{v}, G, U\right)$.

$$
\left.\mathrm{T}_{\mathrm{U}}(\mathrm{U})=\mathrm{T}_{[\overline{\mathrm{T}}}\right]\left(\left[\begin{array}{l}
\overline{0} \\
\overline{1}
\end{array}\right]\right)=\left[\begin{array}{l}
\overline{0} \\
\overline{1}
\end{array}\right]+\left[\begin{array}{l}
\overline{0} \\
\overline{1}
\end{array}\right]=\left[\begin{array}{l}
\overline{0} \\
\overline{0}
\end{array}\right]=\mathrm{C}
$$

Jadi, bayangan $\mathrm{U}=\mathrm{C}$.

Jadi, dari perhitungan di atas diperoleh $\left(\mathrm{C}_{,}, \mathrm{G}, \mathrm{U}\right) \stackrel{\mathrm{T}_{\mathrm{U}}}{\rightarrow}(\mathrm{U}, \mathrm{A}, \mathrm{C})$.

Perhitungan yang sama dilakukan untuk 63 kodon lainnya. Sehingga, multicube pada pengurutan awal $\left(\mathrm{C}_{v} \mathrm{U}, \mathrm{A}, \mathrm{G}\right)$ menjadi

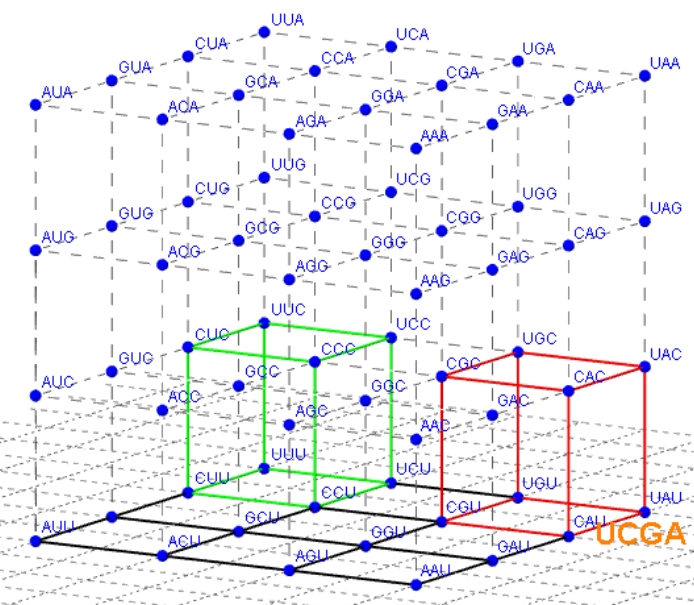

Gambar 5. Model 3 Dimensi $\left(C_{,}, A_{,}, G\right)$ melalui transformasi $T_{U}$ 


\section{Model dan perhitungan untuk $T_{G}$}

Untuk transformasi berupa translasi $T_{G}$, setiap kodon yang menjadi titik sudut multicube pada pengurutan awal $\left(C_{s} \mathrm{U}_{s}, \mathrm{~A}, \mathrm{G}\right)$ diubah pengurutannya menjadi pengurutan $\left(\mathrm{G}_{s}, \mathrm{~A}, \mathrm{U}, \mathrm{C}\right)$. Artinya setiap basa $\mathbf{C}$ diubah menjadi basa $\mathbf{G}$ dan sebaliknya serta setiap basa $A$ diubah menjadi basa $\mathbf{U}$ dan sebaliknya.

Dari pengurutan awal $\left(\mathrm{C}_{v} \mathrm{U}, \mathrm{A}, \mathrm{G}\right)$ misalkan dipilih kodon atau triplet $\mathrm{CGU}=(\mathbf{C}, \mathrm{G}, \mathrm{U})$. Bayangan atau hasil transformasinya diperoleh melalui perhitungan berikut :

- Untuk basa $\mathrm{C}$ urutan pertama pada urutan $\left(\mathrm{C}_{s}, \mathrm{G}_{s} \mathrm{U}\right)$

$$
\mathrm{T}_{\mathrm{G}}(\mathrm{C})=\mathrm{T}_{\left[\frac{\mathrm{T}}{\mathrm{I}}\right.}\left(\left[\frac{\overline{0}}{\overline{0}}\right]\right)=\left[\begin{array}{l}
\overline{1} \\
\overline{1}
\end{array}\right]+\left[\frac{\overline{0}}{\overline{0}}\right]=\left[\frac{\overline{1}}{\overline{1}}\right]=\mathrm{G}
$$

Jadi, bayangan $\mathrm{C}=\mathrm{G}$.

- Untuk basa $\mathrm{G}$ urutan kedua pada pengurutan ( $\mathrm{C}, \mathrm{G}, \mathrm{U})$

$$
\mathrm{T}_{\mathrm{G}}(\mathrm{G})=\mathrm{T}_{\left[\frac{1}{\mathbb{I}}\right]}\left(\left[\frac{\overline{1}}{\overline{1}}\right]\right)=\left[\begin{array}{l}
\overline{1} \\
\overline{1}
\end{array}\right]+\left[\begin{array}{l}
\overline{1} \\
\overline{1}
\end{array}\right]=\left[\begin{array}{l}
\overline{0} \\
\overline{0}
\end{array}\right]=\mathrm{C}
$$

Jadi, bayangan $\mathrm{G}=\mathrm{C}$.

- Untuk basa U urutan ketiga pada pengurutan (C, G, U).

$$
\mathrm{T}_{\mathrm{G}}(\mathrm{U})=\mathrm{T}_{\left[\frac{\mathrm{T}}{\mathbb{I}}\right]}\left(\left[\begin{array}{l}
\overline{0} \\
\overline{1}
\end{array}\right]\right)=\left[\begin{array}{l}
\overline{1} \\
\overline{1}
\end{array}\right]+\left[\begin{array}{l}
\overline{0} \\
\overline{1}
\end{array}\right]=\left[\begin{array}{l}
\overline{1} \\
\overline{0}
\end{array}\right]=\mathrm{A}
$$

Jadi, bayangan $\mathrm{U}=\mathrm{A}$.

Jadi, dari perhitungan di atas diperoleh $\left(\mathrm{C}_{s} \mathrm{G}_{s} \mathrm{U}\right) \stackrel{\mathrm{T}_{\mathrm{C}}}{\rightarrow}\left(\mathrm{G}_{s} \mathrm{C}_{s} \mathrm{~A}\right)$.

Perhitungan yang sama dilakukan untuk 63 kodon lainnya. Sehingga, multicube pada pengurutan awal $(\mathrm{C}, \mathrm{U}, \mathrm{A}, \mathrm{G})$ menjadi

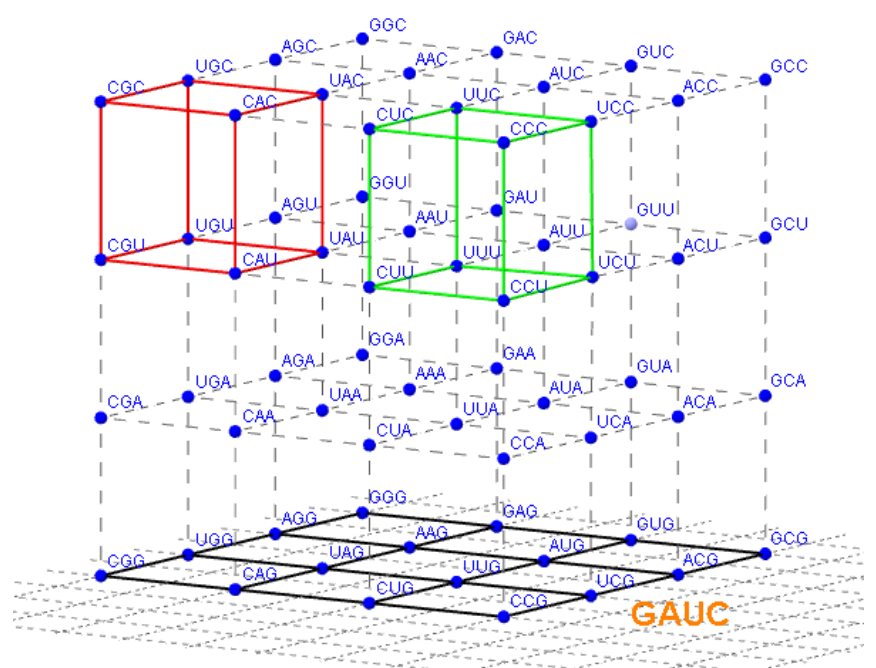

Gambar 6. Model 3 Dimensi $(C, U, A, G)$ melalui transformasi $T_{G}$

\section{Model dan perhitungan untuk $\mathrm{T}_{\mathrm{G}} \circ \boldsymbol{P}_{12}$}

Untuk transformasi selanjutnya yaitu $\mathrm{T}_{\mathrm{G}} \circ P_{12}$, misalkan dipilih kodon yang sama yaitu (C, $\left.\mathrm{G}, \mathrm{U}\right)$. Untuk transformasi komposisi ini, dilakukan dengan terlebih dulu melakukan transformasi dengan matriks $P_{12}$ kemudian dengan transformasi $\mathrm{T}_{\mathbb{G}}$. Melalui perhitungan yang sama, bayangan untuk $(\mathrm{C}, \mathrm{G}, \mathrm{U}) \stackrel{P_{12}}{\rightarrow}(\mathrm{C}, \mathrm{G}, \mathrm{A}) \stackrel{\mathrm{T}_{\mathrm{C}}}{\rightarrow}(\mathrm{G}, \mathrm{C}, \mathrm{U})$.

Perhitungan yang sama dilakukan untuk 63 kodon lainnya. Sehingga, multicube pada pengurutan awal $(\mathrm{C}, \mathrm{U}, \mathrm{A}, \mathrm{G})$ menjadi 


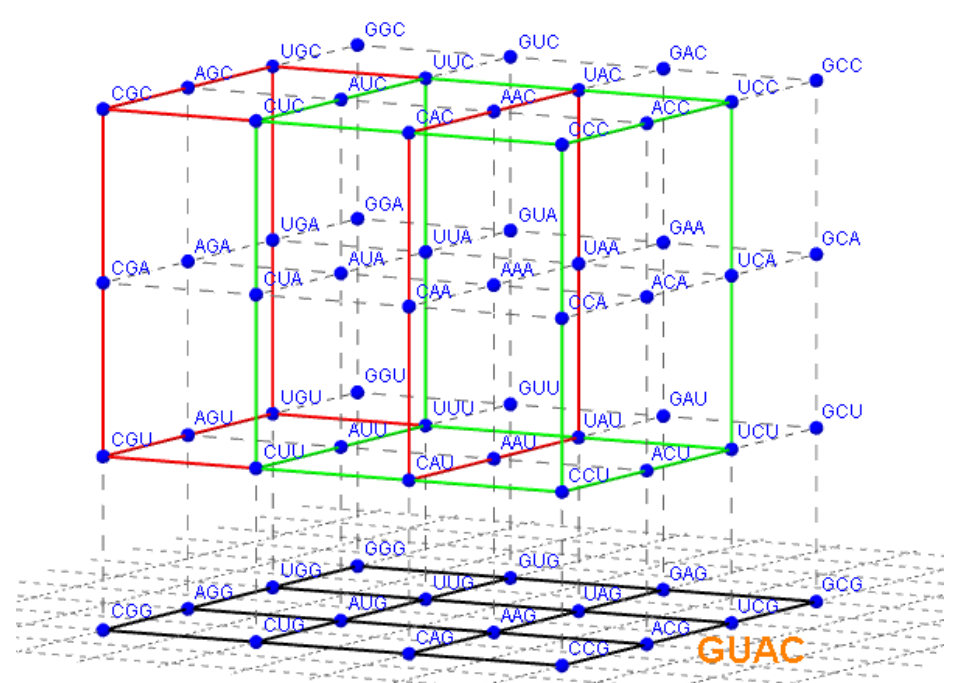

Gambar 7. Model 3 Dimensi ( $\mathrm{C}, \mathrm{U}, \mathrm{A}, \mathrm{G})$ melalui transformasi $\mathbf{T}_{\mathrm{G}} \circ \boldsymbol{P}_{12}$

\section{Model dan perhitungan untuk $\mathrm{T}_{\mathrm{U}} \circ \boldsymbol{P}_{12}$}

Untuk transformasi selanjutnya yaitu $\mathrm{T}_{\mathrm{U}} \circ P_{12}$, misalkan dipilih kodon yang sama yaitu (C, $\left.\mathrm{G}_{s} \mathrm{U}\right)$. Untuk transformasi komposisi ini, dilakukan dengan terlebih dulu melakukan transformasi dengan matriks $P_{12}$ kemudian dengan transformasi $\mathrm{T}_{\mathrm{U}}$. Melalui perhitungan yang sama, bayangan untuk $\left(\mathrm{C}_{s}, \mathrm{G}_{s} \mathrm{U}\right) \stackrel{\mathbb{P}_{12}}{\rightarrow}\left(\mathrm{C}_{s}, \mathrm{G}_{s} \mathrm{~A}\right) \stackrel{\mathrm{T}_{\mathrm{U}}}{\rightarrow}\left(\mathrm{U}_{s} \mathrm{~A}_{s} \mathrm{G}\right)$.

Perhitungan yang sama dilakukan untuk 63 kodon lainnya. Sehingga, multicube pada pengurutan awal $(\mathrm{C}, \mathrm{U}, \mathrm{A}, \mathrm{G})$ menjadi

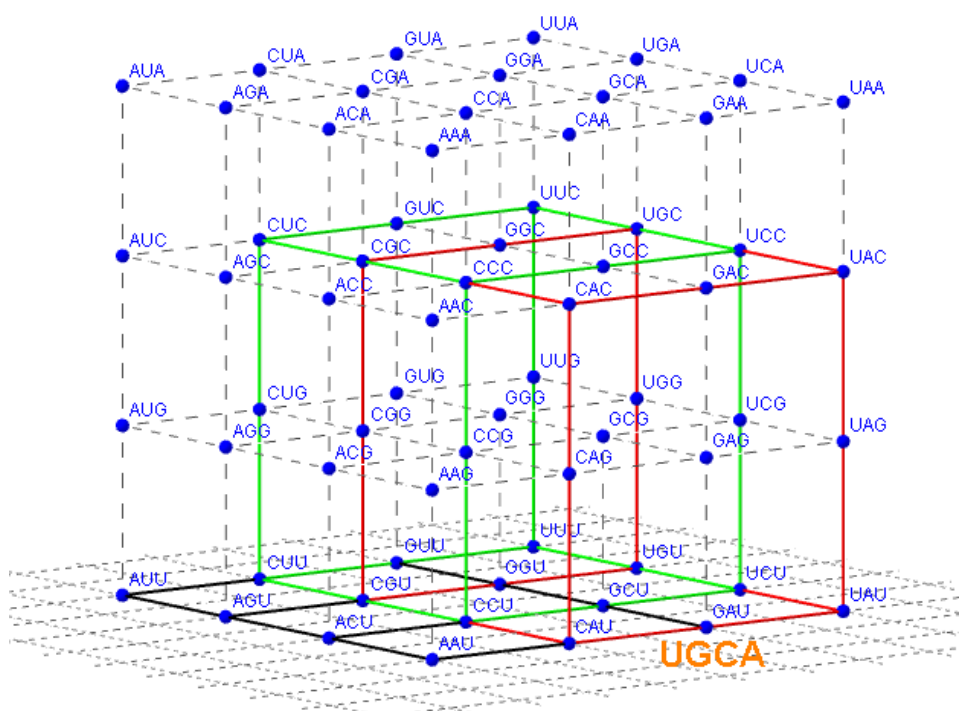

Gambar 8. Model 3 Dimensi $\left(C, U_{v}, A, G\right)$ melalui transformasi $\mathbf{T}_{U} \circ \boldsymbol{P}_{12}$

\section{Simpulan}

Dari uraian di atas dapat disimpulkan dengan menggunakan bantuan Software Geogebra dapat dilihat representasi Mutasi dari Kode Genetik Standar berdasarkan basa nukleotida yaitu perubahan dari $\{C, U A, G\}$ menjadi : $(G, A, U, C),(U, C, G, A),(U, G, C, A)$ dan $(G, U, A, C)$. 


\section{Daftar Pustaka}

1. Herstein, I.N., 1964, Topics in Algebra, London : Ginn and Company.

2. Jose, Marco V et al, 2006, An Extended RNA code and its Relationship to The Standard Genetic Code : An Algebraic and Geometrical Approach, Bull.Math.Biol, 2007 (69) : 215-243.

3. Pratiwi, D.A. dkk., 2012, Biologi Untuk SMA/MA Kelas XII, Jakarta : Penerbit Erlangga.

4. Robinson, J.S Derek, 2003, An Introduction to Abstract Algebra, New York : Walter de Gruyter. 
Aisah et al.,/ JMI Vol 11 No 1 April 2015, Pp. 25 - 34 